\title{
The Rise and Fall of the Forsytes: From Neo-Victorian to Neo-Edwardian Marriage
}

\author{
Sarah Edwards
}

\begin{abstract}
:
This essay will argue for the usefulness of examining both 'neo-Victorian' and 'neoEdwardian' representational practices in the debates about marriage that dominate John Galsworthy's novels A Man of Property (1906) and In Chancery (1920). The 'neo-Victorian' and 'neo-Edwardian' frequently intersect in these texts, but are also placed in opposition, for example, as symbols of tradition and modernity. I consider how this Edwardian novelist employs narrative strategies to distance himself from recent historical events and introduces specifically Edwardian debates (on divorce reform and the modern country house) to promote new models of married life, and how he uses the Boer War to consider the relationship between imperial and domestic possessiveness. I then briefly consider how the 1967 and 2002 television dramatisations of the novels (as The Forsyte Saga) erase, modify or expand Galsworthy's tropes; and how their critical and popular reception illustrates the developing role of both neo-Victorian and neo-Edwardian discourses in shaping debates about marriage in the particular historical circumstances of the 'Swinging Sixties' and post-millennial Britain.
\end{abstract}

Keywords: adaptation, country house, divorce, Forsyte Saga, John Galsworthy, marriage, neo-Edwardian, nostalgia, television series.

\section{Introduction: Bridging the Centuries}

In a review of the 1967 BBC television production of Galsworthy's Forsyte Saga, the writer congratulated the scriptwriter's achievement in depicting "the whole Forsyte clan in its Victorian power and splendour [...] that are so essential to a full understanding of the family's decay" (Anon. 1967: n.p.). By contrast, a review of the 2002 Granada production attributed the Forsytes' continuing popularity to a different historical and narrative trajectory: "the first volume [...] 
appeared at the peak of Edwardian bourgeois wealth and confidence. By the time the ninth volume appeared, the Great War had come and it was nearly all over". For this reviewer, The Forsyte Saga was a "major story of Englishness", depicting "a time when Britain was rich and powerful" and "the family was everything", portraying "a class and nation at its last great moment, before the collapse following the First World War" (Bradbury 2000: n.p.).

These reviews indicate both the lengthy composition process of The Forsyte Saga, by an author whose perspectives on the late Victorian and Edwardian settings of his fictions were modified through the processes of time, memory, personal and cultural change; and its adaptation and reception many decades later by audiences who attached a range of different meanings to, and emotional investments in, the 'Victorian' and 'Edwardian' eras. Galsworthy's first novel, $A$ Man of Property (published in 1906, but set in 1886), was intended as a critique of Victorian values, especially the conflation of material property and 'possessive' marital relationships, so aptly indicated by its title. It is a semi-autobiographical text informed by Galsworthy's own ten-year affair with his future wife Ada, who was unhappily married to her cousin. They were finally able to marry in 1905, when Galsworthy began writing his novel, one of the earliest examples of neo-Victorian writing about the family. In 1915, Galsworthy wrote a short interlude, 'Indian Summer of a Forsyte', set in 1892, but he did not write the second novel, In Chancery, until 1920. For the setting of this novel he chose the years 1899-1901, and the work closes with a series of reflections on the cultural import of the shift from the Victorian to the Edwardian age. Also in 1920, he wrote another interlude, 'Awakening', set in 1909. These two novels and interludes, and their subsequent dramatisations, will be the focus of this essay, which will argue that reading the saga as a series of both "neoVictorian' and 'neo-Edwardian' texts enables a better understanding of the different ways and range of media in which the Forsyte marriages have been represented at various historical moments.

The now familiar critical term 'neo-Victorian' is often employed in analyses of 'neo-Edwardian' texts, which might be located in both the Victorian and Edwardian periods, or engage in 
reflections on the dawn of the twentieth century. ${ }^{1}$ Are the two periods and terms more or less indistinguishable, or does the first decade of the twentieth century demonstrate particular trends that are partially constituted by the death of a queen and the beginning of a new century? In the literary and popular imagination, what historical events and cultural attitudes are people invoking when they reference the Edwardians, as opposed to their immediate predecessors? Are these events and attitudes then subsumed by the 'neo-Victorian' in a form of coverture that echoes Victorian conceptions of marriage? This latter tendency illustrates the risks of what Ann Heilmann and Mark Llewellyn have labelled the "homogenized identity" that "the Victorian' has become [...] in contemporary culture" and the ways in which this homogenisation might be (erroneously) replicated in scholarly work (Heilmann and Llewellyn 2010: 2). The nine years from 1901-1910, then, are often imagined as part of a long nineteenth century in academic journals such as Interdisciplinary Studies in the Long Nineteenth Century or Victoriographies.

However, J.B. Bullen has shown how the term 'Victorian' was used during the Edwardian period to connote a distinctly different set of values, at the same time acquiring the Oedipal resonances which scholars often trace to the 1960s instead (Bullen 1997: 2; Kaplan 2007: 86). This decade is usually credited with the birth of the neoVictorian novel, with the notable publications of Jean Rhys's Wide Sargasso Sea (1966) and John Fowles's The French Lieutenant's Woman (1969). Yet the definition of 'neo-Victorianism' is still being debated, with respect to both its historical and ideological parameters. Heilmann and Llewellyn have usefully suggested that texts identified as "neo-Victorian" are "self-consciously engaged with the act of (re)interpretation (re)discovery and (re)vision concerning the Victorians" (Heilmann and Llewellyn 2010: 4, original emphasis). Cheryl A. Wilson's analysis of Joseph Conrad's The Secret Agent (1907), published only a year after A Man of Property, suggests that this early modernist work already exhibits neo-Victorian preoccupations, such as the relationships between history and fiction and the self-conscious use of time, juxtaposed with Victorian constructions of class and gender (Wilson 2008). However,

\footnotetext{
${ }^{1}$ Examples include A.S. Byatt's The Children's Book (2009) or Julian Barnes's Arthur and George (2005).
} 
Galsworthy, unlike Conrad, is not a canonical modernist writer. Instead, he has been associated with the Edwardian 'middlebrow' decade before the advent of the Georgian poets and high modernism and with the nostalgic appeal of a final golden age of British imperial power before the catastrophe of World War One (Woolf 1923; Batchelor 1982: 2; Ardis 2002: 114). However, the term 'Edwardian' possesses shifting connotations. It is also included in accounts of modernity, linked to the decadence of the fin-de-siècle and the technological triumphs of the new century (Batchelor 1982: 3). ${ }^{2}$ Other scholarly accounts have also identified the Edwardian period as an age of transition, and this concept is often used to assess Galsworthy's accounts of Victorian society (see Miller 1997). For example, Alison Hargreaves suggests that the Forsyte Saga is "operating in the transitional cultural context of the Victorian, Edwardian and Modernist periods" and functions as Galsworthy's negative commentary on emergent modernism (Hargreaves 2007: 128). Within this transitional literary culture, Galsworthy himself has been described (most notably by Virginia Woolf) as the quintessential Edwardian writer: a social realist, resolutely middlebrow and materialistic, as much identified with, as opposed to, the Victorian possessive instincts of his fictional creations (see Woolf 1966). D.H. Lawrence's judgement on A Man of Property has also exerted lasting critical weight, especially his claim that it "has the elements of a very great novel, a very great satire. It sets out to reveal the social being in all his strength and inferiority. But the author has not the courage to carry it through" (Lawrence 1928: 122).

It is precisely this tension in Galsworthy's fiction - between his simultaneous identification with, and rejection of, his Victorian past - that identifies him as a neo-Victorian writer in transition from the Victorian age. Furthermore, Galsworthy's materialism is both an important site of his social critique and an example of his continued allegiance to Victorian realist aesthetics. For example, he utilises contemporary debates on cutting-edge design to demonstrate how modern architecture transformed later Victorian conceptions of married life, while still employing the narrative conventions of Victorian realism. Ultimately, I will suggest that Galsworthy (who,

\footnotetext{
${ }^{2}$ In 2007, BBC4's season of programmes, The Edwardians, was subtitled 'The Birth of Now'.
} 
like most Edwardians, had been born and raised as a Victorian) instates the 'Edwardian' as a modern, albeit nostalgic and utopian, alternative. In the later texts of The Forsyte Saga, written and published in 1920, when Galsworthy re-visits and re-imagines both the Victorian and Edwardian periods, his neo-Edwardian aesthetic helps us to better understand the recuperation of the Saga at particular historical moments and the dynamic between the neo-Victorian and the neo-Edwardian marriage. The Edwardian period has served a range of political and aesthetic purposes vis-a-vis its historical antecedent at different historical moments, which have helped to shape the appeal of The Forsyte Saga.

\section{The Neo-Victorian Edwardian Novelist}

In 1906, when A Man of Property was published, reform of the Victorian divorce laws was an increasingly topical issue. The law had basically remained unchanged since the Matrimonial Causes Act of 1857. In order to obtain a divorce, women had to prove adultery and one further offence (usually desertion for two years or cruelty), while men had only to prove adultery. The procedure, then, was inherently patriarchal and combative, and led to the malicious contrivances satirised in In Chancery, whereby Soames instructs a private detective to follow Irene for evidence of her non-existent lovers: "perhaps you will be good enough, then, to give me information on which I can act. The law must be complied with" (Galsworthy 1920: 83). ${ }^{3}$ Otherwise, the only alternative was separation, enshrined in the acts of the 1880 s and 1890s. This left couples like Soames and Irene in a permanent limbo, mused on by Soames: "twelve years is a long time [...] I-I'm tired of it" (Galsworthy 1920: 50). It also jeopardised the possibility of bearing children who might inherit property and provide emotional solace. The importance of a Victorian developmental narrative of marriage, children and inheritance for a sense of identity and purpose is often uttered by Soames, who feels that his life goes aimlessly "on and on" but "without object" (Galsworthy 1920: 221). Several reform bills, which aimed to equalise the law, had been submitted to - but rejected by - the House of Commons, in 1902 and 1903 respectively. The Royal Commission on divorce did not meet until 1910-12, but a

\footnotetext{
${ }^{3}$ For ease of differentiation, Galsworthy references employ the first publication dates of his texts, rather than the 2007 date of the modern editions consulted.
} 
number of controversial cases in the Edwardian era caused much topical debate, while guidance manuals on 'modern marriage' were increasingly ubiquitous and the divorce novel was becoming a recognisable genre. ${ }^{4}$ Soames's belief, then, in the inevitable progression of marriage, children and patriarchal inheritance, seemed distinctly mid-Victorian in this context. Jane Eldridge Miller notes that Edwardian divorce novels such as Galsworthy's developed from the New Woman fiction of the 1880s and 1890s, the plots of which often featured a bad marriage as one of the trials in the heroine's bildungsroman (Miller 1994: 39-84). Both these works and Galsworthy's fiction also share generic features with the sensation novels of the 1860s, such as Mary Elizabeth Braddon's Lady Audley's Secret (1862) or Wilkie Collins's The Woman in White (1859-60). In particular, Braddon's sensational account of an aristocrat's disastrous marriage contains several plot and character devices which Galsworthy employs in his depiction of middle-class married life: a blonde, enigmatic heroine who is driven by poverty into marriage with an older, wealthy man and who consequently becomes the perpetrator of marital transgression. In Irene Forsyte, Collins's amoral bigamist and would-be murderess Lady Audley is transformed into a sympathetic adulteress with a violent husband, but both novels condemn the structures of Victorian marriage which largely determine their heroines' choices. Evidently, Galsworthy drew on melodramatic Victorian fictions that thinly veiled their criticisms of middle-class Victorian society through the use of aristocratic settings and improbable events. A whole range of Victorian fictional conventions employed in these novels, including the family saga and Gothic themes, are embedded within Galsworthy's realism.

The Forsyte Saga, then, is an important example of the Edwardian divorce novel that made the destruction of Victorian marriage the subject of modern fiction. The genre developed a host of new plot structures to deal with the formal consequences of a shift away from the mainstream Victorian novel's equation of marriage with closure, the restoration of community and the expulsion of antisocial characters. These structures included the courtroom trial, the two-suitor plot and the sympathetic adulterous wife. The Man of

\footnotetext{
${ }^{4}$ See, for example, Maud Churton Braby's Modern Marriage and How to Bear It (1909) and Mary Augusta Ward's novel Marriage a la Mode (1909).
} 
Property conflates all of these structures in the figure of Bosinney, the itinerant architect whom Soames sues for cheating him over his property - both his house and his wife. Much critical attention has already been devoted to Galsworthy's exposé of the possessive and patriarchal nature of Soames's and Irene's marriage. Instead I want to focus on how Galsworthy echoes and develops some of the themes of his Edwardian contemporaries on divorce, but employs a range of neo-Victorian narrative strategies to create a critical dialogue between the formal, thematic and ideological preoccupations of the near Victorian past and the Edwardian present.

Galsworthy employs several narratives of 'rise and fall', which he alternately endorses and undermines. This narrative trajectory distances a Victorian generation that many contemporary readers would have known. Instead of imagining the recent past in dialogue with a progressively unfolding present, Galsworthy writes of a Victorian family whose narrative ending is foretold in chapter one. For example, many scholars have noticed the precise dating of the saga, most famously in the opening sentence of $A$ Man of Property "on June 15, 1886, about four of the afternoon" - we witness the "“highest efflorescence' of the family 'tree"” (Galsworthy 1906: 3). As Lynne Hapgood observes, this scene evokes stable and familiar images - tea, summer, middle-class routine - but it is immediately identified as a moment of transition (Hapgood 2000: 162). We are primed, then, to await decline and fall throughout the remainder of the novel as, for example, in the chapter devoted to the funeral of the Forsyte matriarch Aunt Ann, who was born in 1802, is nearly as old as the century and, ominously, "had died while the tree was yet whole" (Galsworthy 1906: 100). This episode also demonstrates how Galsworthy evokes an acute sense of historical change within the nineteenth century and sharply differentiates between family - and Victorian - generations. This contrasts with later neo-Victorian depictions, which sometimes produce more monolithic accounts of the period. ${ }^{5}$ Galsworthy repeatedly differentiates, then, between early and later Victorian attitudes to sexuality and marriage. In 'Indian Summer of a Forsyte', set in 1892, Irene and Old Jolyon discuss relationships

\footnotetext{
${ }^{5}$ An example of this is Lytton Strachey's Eminent Victorians (1918), as its title implies. It seems that the horrors of the First World War produced this sense of distance and the caricaturing of the whole period, as the conflict intensified Strachey's loathing of Victorian imperialism.
} 
between men and women and "a glimpse of light on the inexorable nature of sex antipathies strayed into a brain", which belonged to "early Victorian civilisation" and "had never thought about such primitive things" (Galsworthy 1915: 346). Galsworthy's emphasis on generational difference in his family saga acts as a corrective to later neo-Victorian writers, including Bloomsbury modernists such as Strachey, who often represent the Victorians as a sexually repressed mass in sharp contrast to their liberated descendants. Instead, Galsworthy distances the Edwardian reader from the high Victorianism of early and mid-century.

Galsworthy locates an important moment of transition in the 1880s and identifies the Married Women's Property Act (1882) as a defining factor. This ground-breaking piece of legislation marked a decisive shift from the Victorian marital discourse of coverture, by recognising a wife's individual legal identity and enabling married women to retain control of their separate property. A reference to the Act is carefully inserted near the start of the text, foregrounding its importance for the themes of property and marriage, and for the novel's transition from high Victorian values. Nicholas Forsyte had married "a good deal of money" in "the golden age before the Married Women's Property Act" and so had "mercifully been enabled" to "make a successful use" of it (Galsworthy 1906: 19). This passage, which negates the humanity of his anonymous wife, neatly illustrates the wider cultural conflation of women, marriage and property that the Act helped to unravel. Meanwhile Soames, whose strong allegiance to his parents' generation is indicated by his being "born in the year of the Crimea" (1854), expresses the sense of disorientation that the concept of divorce induces: "a divorce! Thus close, the word was paralysing, so utterly at variance with all the principles that had hitherto guided his life" (Galsworthy 1906: 287). Divorce, then, becomes associated with the transition towards modernity and, fittingly, Soames's and Irene's divorce is granted in 1900.

Alongside the decline of the Forsyte patriarch and matriarch in the final decades of the nineteenth century, both of whom are identified with high Victorian values, the novels chronicle the births and growing maturity of the children of Soames and his contemporaries. These children are identified in In Chancery as "The Third Generation", who, according to young Jolyon, "open the ball of the new century" when "ideals are mixed" (Galsworthy 1920: 111, 
117, 114). They are another focus for Galsworthy's critique of Victorian possessiveness: on the one hand, Soames's longing for a son constructs the child as an abstract entity, merely an heir "to leave his money to", as his cousin June says scornfully (Galsworthy 1920: 133). However, the child is also depicted as a source of renewal for the ageing bachelor figure whose lack of contact with younger family members is, by implication, isolating him from modernity (Gavin 2009: 62). In this and other respects, Galsworthy draws on recognisably Edwardian models of childhood as a corrective to Victorian possessive attitudes. Adrienne E. Gavin and Andrew F. Humphries have noted that the Edwardians developed a "cult of childhood", regarding the child as a "symbolic counterweight" to the "stresses of modern life and a civilisation felt to be in decline" (Gavin and Humphries 2009: 2). Soames undoubtedly concurs with the notion of decline, reacting with horror to a "mob" he encounters in 1900 and declaring that their behaviour "wasn't English". At this time, his thoughts of "a son...to be taken on his knee", who would "understand, and comfort him", are not only characterised by possession and inheritance, but by the possibility of an emotional connection that he failed to discover in marriage (Galsworthy 1920: 210, 237, original ellipses). The nature of this connection is expanded on in the account of old Jolyon's declining years as a widower, which are comforted by "that tenderness for little children" which his grandchildren inspire (Galsworthy 1906: 80). As I will go on to discuss further in relation to the neo-Edwardian 'Awakening', Galsworthy draws on the pastoral conventions of Edwardian children's literature in these brief episodes, frequently picturing the family group in the garden and associating his "small creatures" with loyal domestic animals (Galsworthy 1906: 81). These episodes are partly presented from the children's point of view, where, however, their possessive instincts towards their favourite objects is clearly evident. By 1899, at the start of In Chancery, the narrator remarks that the third generation "preferred to concentrate on the ownership of themselves, conforming to the growing tendency fin de siècle it was called" (Galsworthy 1920: 6).

Galsworthy's perception of fin de siècle as a license for rampant individualism is underscored by the link he makes to the Boer War, whereby "the Colonial disposition to own oneself ... is the paradoxical forerunner of Imperialism" and is "making progress all the time" (Galsworthy 1920: 5, original ellipses). This ironic comment 
indicates that Galsworthy problematises a simple linear model of progress from benighted Victorian to enlightened Edwardian values. In the wake of a new outbreak of imperial aggression at a time when women and children were developing new models of individual selfhood, it was imperative that they did not imitate the possessive instincts of their menfolk. Young Jolyon, often seen as Galsworthy's mouthpiece, makes an explicit connection between marriage and imperialism: "domination of peoples or of women! Attempts to master and possess those who did not want you!"(Galsworthy 1920: 196197). However, what has been less frequently remarked upon is the possessive instincts of the turn-of-the-century married woman herself. Soames's sister, Winifred, is also seeking a divorce and, like her brother, conflates property and spouse: "without her husband, without her pearls [...] she felt bereaved indeed" (Galsworthy 1920: 29). It is significant that her husband Dartie runs away to Latin America, a European colony, with an Argentinian dancer, a "Spanish Jade" and, on his return, Winifred thinks in military terms that "she had won a sort of victory, retained her property" (Galsworthy 1920: 17, 205). Like many late Victorian and Edwardian middle-class women (and feminists), Winifred exhibits a sense of class and racial superiority towards colonial subjects, with whom Dartie becomes conflated due to his lack of money (Delap et al. 2006: v-lx). This divorce, then, indicates that the turn-of-the-century woman's growing access to property may serve to make her as possessive and materialistic as her male counterparts.

This anxious sense of transition is also reflected in the ways that Galsworthy's characters dramatise and debate some of the key concepts of Victorian marriage and divorce, seeking to re-define their meanings, but only revealing their opacity and complexity. For example, the definition of a marital crime is debated when Irene tells Soames that it was a "crime to marry you" (Galsworthy 1920: 84). Meanwhile young Jolyon feels that denying his and Irene's love is a greater crime than adultery: "the notion of standing in a witness box and swearing to the truth that no gesture, not even a word of love had passed between them" seems "more degrading than to take the tacit stigma of being an adulterer" (Galsworthy 1920: 240). In this reversal of conventional values, the public, legal and static definitions of marital roles distort and misrepresent the emotional realities of a private relationship. However, this privileging of private emotion 
itself causes marital complications and misreadings of the other's motives. Soames asks Irene: "what made you refuse me so often? She had answered by a strange silence. An enigma to him from the day that he first saw her" (Galsworthy 1906: 109). This self-conscious musing on the unknowability of another suggests that Soames is starting to realise the inadequacy of his Victorian view of beautiful, enigmatic Irene as a decorative angel in the house. Instead, it seems that Irene's much-noted lack of interiority hints at a proto-modernist conception of character. Within the context of marital reform, Galsworthy may be subverting the image of the silent Victorian wife to indicate that the strangeness and unknowability of others - whose inner selves cannot be possessed - demonstrates the need for a new conception of marriage that respects separateness and individuality rather than complete possession of the female. ${ }^{6}$

Galsworthy's use of the opaque London fog increases the characters' sense of uncertainty and disorientation in a world of transitional values. Although the fog is best remembered as the plot device which precipitates Bosinney's mysterious demise under the wheels of a carriage, it is also deployed as a symbol on the morning after Soames's rape of Irene. Soames's assertion of his marital rights is undermined by his tortured internal questioning of religious and Victorian discourses: "had he been right", he asks himself, "to yield to his overmastering hunger of the night before, and break down the resistance which he had suffered now too long from this woman who was his lawful and solemnly constituted helpmate?" (Galsworthy 1906: 265). This chapter, entitled 'Voyage into the Inferno', endows the mundane domestic imagery of the Edwardian breakfast table and bedroom with ominous mystery: "he breakfasted by gaslight, the fog of late November, wrapping the town as in some monstrous blanket till the trees of the square even were barely visible from the diningroom window"; unnerved by the menacing atmosphere, "he was still haunted by the odd, intolerable feeling of shame and remorse he had felt, as he stood looking at her by the flame of the single candle, before silently slinking away" (Galsworthy 1906: 265). Again, Galsworthy draws on Victorian melodrama to undermine Victorian

\footnotetext{
${ }^{6}$ Examples of the silenced and unknowable Victorian wife include Louisa Gradgrind in Charles Dickens's Hard Times (1854) or Mrs Rucastle in Arthur Conan Doyle's 'The Adventure of the Copper Beeches' (1892), which is strongly influenced by the figure of the silenced madwoman in Charlotte Brontë's Jane Eyre (1847).
} 
legal discourses, as these images of fog, gaslight and the ghostly darkened city are drawn from the new urban Gothic fiction of the $1890 \mathrm{~s}^{7}$ At the same time, the claustrophobic seeping of this atmosphere into the home endows it with the same terrors that earlier heroines of female Gothic such as Charlotte Brontë's Jane Eyre endured from patriarchs in antique mansions.

The importance of domestic spaces in The Forsyte Saga as Victorian symbols of familial and material possession has frequently been commented on. For many critics, the construction of Galsworthy's fictional houses marks his novels as characteristically Edwardian and as a continuation of Victorian realist aesthetics in a proto-modernist literary climate. Woolf famously observed in ' $\mathrm{Mr}$ Bennett and Mrs Brown' that Edwardian novelists failed to realise that "novels are in the first place about people, and only in the second about the houses they live in" (Woolf 1966: 332). Subsequent critics have protested that the Forsyte residences are metonyms intended to symbolise their inward obsession with status and possession (Miller 1994: 39-84). Indeed, Galsworthy's narrator declares that "without a habitat, a Forsyte is inconceivable - like a novel without a plot" (Galsworthy 1906: 85); and at the end of the novel, when Soames regains possession of Irene following the death of her lover Bosinney and announces "we are not at home [...] and in young Jo's face he slammed the door" (Galsworthy 1906: 317), he indicates that his home is literally the seat of his marital authority. Although young Jolyon expresses his outrage at Soames's treatment of Irene, the positioning of this incident at the close is ambiguous. Soames's reinstatement of patriarchal authority through this act mirrors the conservative restoration of the status quo typical of the Victorian novel. Despite his interpolation of Gothic and melodramatic elements, Galsworthy still reproduces the patriarchal conservatism of the system by framing his novel with the conventions of Victorian realism.

The same tensions of meaning, between neo-Victorian critique and Victorian aesthetics, are produced in the descriptions of the houses themselves. Little critical attention has been paid to the detailed accounts of the various houses' interior designs, especially

${ }^{7}$ See, for example, the descriptions of London in The Picture of Dorian Gray (1891) and The Strange Case of Dr Jekyll and Mr Hyde (1886). 
Soames's country house, Robin Hill, and the symbolic role that its modern decoration plays in the transition away from high Victorian values. By contrast, Timothy Forsyte's cluttered interior is designated as typically mid-Victorian in design, reflecting his outdated views more generally: "Timothy and his sisters, following the tradition of their generation, considered that a room was not quite nice unless it was properly furnished [...] eleven chairs, a sofa, three tables, two cabinets" (Galsworthy 1906: 165). This interior mirrors the home's stultifying claustrophobia and its occupants' rigid traditions, for example, eating mutton at dinner parties (Galsworthy 1906: 42). By contrast, Soames's town house "favoured the First Empire and William Morris". It combines, then, the Regency style of the earlier nineteenth century (typified by the "handsome rosewood table" and lustrous colour schemes including "jade-green tiles"), with instances of Arts and Crafts and other modern aesthetic design, such as the "Japanese sunshade". (Japanese objects, with their simplicity and boldness of form, became very fashionable in the later part of the century with the rise of Aestheticism.) This design combination symbolises Soames's allegiances to the past and his efforts at modern and original tastes. However, the narrator mockingly observes that his home "bears a close resemblance to hundreds of other houses with the same high aspirations". Soames, then, is as enslaved to late Victorian middle-class mores as his parents' generation are to mid-Victorian clutter, and he reproduces the same rigid domestic routines - for him, "hot dinner on Sundays" (Galsworthy 1906: 60-61).

Irene's artistic temperament is only satisfied by a man whose interior designs herald a new style of living in the twentieth century. Bosinney is "one of the new school of architects" who has been abroad to study "foreign architecture" (Galsworthy 1906: 53, 86). The design of Soames's country house Robin Hill (set several miles outside London), has not been commented on in any detail, although its interior design dominates several chapters. Hapgood notes that between 1886 and 1906, the idea of the suburbs was being re-defined and that their social and spatial geography was crucial to contemporary realist fiction and its commitment to modern (rather than modernist) living. She claims that Galsworthy recognised "their significance as the locus of the future" (Hapgood 2000: 163). Soames commissions Bosinney to design and build a country house in Surrey, both to add to his gentlemanly possessions and to cloister his most 
prized possession, Irene, from public admiration in London. Mark Girouard has noted that by 1900 the "new rich" were buying or building these smaller country houses, often influenced by the associations of peace, beauty and tradition that were depicted in publications such as Country Life, launched in 1897 (Girouard 1994: 303). Hapgood, however, underestimates the importance of modern aesthetics in the account of Robin Hill.

Bosinney's creation at Robin Hill is described thus: a "rectangular house of two storeys was designed in a quadrangle round a covered court. This court, encircled by a gallery on the upper floor, was roofed with a glass roof" while "the decoration was really in excellent taste" (Galsworthy 1906: 89). Further depictions of the interior focus on its "dull ruby tiles that extended from the foot of the walls" and "purple leather curtains drawn along one entire side", as well as the "black oak floor and [...] walls [...] of ivory white" (Galsworthy 1906: 224). Late nineteenth-century country houses often exhibited a revival of neo-classical symmetry. However, while Bosinney's plan contains elements of neo-classical design in its "eight columns", the extensive use of glass and the rectilinear designs (for Soames, the house resembles a "barrack") anticipates the modern movement in architecture of the early twentieth century (Galsworthy 1906: 90). The interior design of Robin Hill seems influenced by Arts and Crafts designers such as Charles Rennie Mackintosh or Charles Voysey, whose late Victorian and Edwardian country houses featured open spaces, white walls, straight lines and minimalist design, and Edward Godwin, who was greatly influenced by the Anglo-Japanese style and often used black wood. Bosinney's house, then, exhibits cutting-edge design trends that came to still greater prominence in the early twentieth century. ${ }^{8}$

Soames, however, reveals his mid-Victorian sensibility with the judgment that there is a "lot of room cut to waste", which prompts Bosinney to deliver a satiric monologue on Victorian (and Forsyte) decoration: "we load our houses with decoration, gimcracks, corners, anything to distract the eye". Instead, he declares with modern

\footnotetext{
${ }^{8}$ The production designer of the 2002 television adaptation justified his use of Frank Lloyd Wright's designs: "So I thought, well, if Frank Lloyd Wright could do that in 1890, then Philip Bosinney can do it in 1883. I've cheated by seven years, but my excuse is that Bosinney is just way, way ahead of his time" (qtd. PBS n.d.).
} 
enthusiasm, "get your effects with a few strong lines". He also characterises the ideal occupant of his house as the modern "gentleman" who values "space, air, light", rather than complaining about them as Soames does, and likes "room to breathe" (Galsworthy 1906: 89-91). This open space facilitates new domestic arrangements which contrast sharply with the feelings of entrapment and claustrophobia that Irene experienced in Soames's town house. Ultimately, Irene and young Jo pursue a non-marital (and nonpossessive) sexual relationship in the new house, where they both "have room to breathe". They forge a mutually giving relationship that respects the individuality of the other.

Galsworthy's clear allegiance to progressive reform of Victorian legislation, and of cultural attitudes in areas as diverse as the Boer War and interior design, identify him as an early neo-Victorian writer. However, the tacit identifications with Forsyte materialism, which Woolf and Lawrence identified in his work, is largely attributable to his deployment of Victorian narrative practices. Hence, his account of modern design trends remains paradoxically rooted in conventional visual descriptions of the house's architecture and decoration. He does not explore the interiority of Irene, so her experience of non-possessive sexuality in the house is never evoked. Hence, she is another beautiful object: both a neo-Victorian representation of the wronged wife and a Victorian image of beautiful passivity and suffering.

\section{From Neo-Victorian to Neo-Edwardian Marriage}

In a statement which mythologised Galsworthy's resumption of The Forsyte Saga in 1920, his biographer R.H. Mottram claimed that "there was a considerable feeling just then for continuity, for reaching back and linking up with the Peace we had once known" and that Galsworthy's "resumption of the Forsyte theme chimed in with a very general if not very articulate sentiment in those days" (Mottram 1956: 197). These remarks both indicate the growing nostalgic tendency of later twentieth-century commentators to idealise a historically undifferentiated pre-War idyll, and the striking contrast between the depiction of inarticulate longing with which Galsworthy is identified and the reflective, precisely-dated novel which he actually wrote. As I indicated earlier, Galsworthy's attitude to the new century was ambivalent, both celebrating and deploring the growing individualism 
that could lead to either the Boer War or to non-possessive marriages. I suggest, however, that he ultimately endorses Irene and Jolyon's relationship as a workable modern marriage through the use of Edwardian pastoral conventions, which displace the Victorian narratives that limit his characters.

Galsworthy's most sustained commentary on the turn of the century's significance is the chapter devoted to Queen Victoria's funeral, 'Passing of an Age'. Following his second marriage, to Annette, Soames and the other Forsytes watch the funeral procession. As Soames considers this "summing-up" of the Victorian age (Galsworthy 1920: 264), the voices of the crowd invade the narrative. At times these diverse and conflicting voices compose a collective stream-of-consciousness that eludes the control of the narrator, mirroring the Victorian patriarch Soames's unease amongst the nondeferential crowds of the twentieth-century city. This "surging, great, dark-coated crowd" exhibit an "unconscious, deep, primitive, wild" sorrow at the loss of the matriarch of the nation-family (Galsworthy 1920: 265, 267). Yet their primal sorrow is articulated as a mixture of nostalgia and hostility -"things would never be as safe again as under good old Viccy", but "never again would a Queen reign for so long or people have a chance to see so much history buried for their money [...] a pity the war dragged on" (Galsworthy 1920: 266, 265). The collective sadness at Queen Victoria's death is represented, then, as the loss of maternal plenitude: primitive, largely unconscious and unreasoning. By contrast, the progressive and rational adults celebrate the dawn of the new Edwardian era. Within the crowd are the lovers Irene and Jolyon, cast in Soames's Victorian mind as "inherently illicit creatures, rebels from the Victorian ideal" (Galsworthy 1920: 266). They form an enduring family only once the Victorian matriarch is dead, and their modern partnership is symbolised by the birth of their child in 1901.

These "dark-coated" (Galsworthy 1920: 265) images of Victorianism stand in contrast to the narrative trajectory of a "golden age" (Galsworthy 1906: 19), which has a complex function in the saga. It is often used by Galsworthy to ridicule nostalgic fantasies which conceal the possessive realities of Victorian marriage, as I observed earlier about the Forsytes' wistful remembrances of the age before the Married Women's Property Act. Similarly, Soames remembers his first meeting with Irene in a pastoral setting: 
"memories crowded on him with the fresh, sweet saviour of the spring wind [...] memories of his courtship", which are soon undercut "by his enquiries into her stepmother's wealth" (Galsworthy 1906: 108). In Chancery attempts to negotiate the tension between Victorian stasis and tradition, on the one hand, and development and change, on the other, through the medium of country-house nostalgia. This seems another example of Galsworthy's oscillation between Victorian resolution and neo-Victorian deconstruction of this achieved harmony, or what Hargreaves has described as Galsworthy's tension between nostalgic recuperation of pastoral, unchanging England and the novel as a force for social change (Hargreaves 2007: 129). Thus, while Bosinney's house is an exemplum of modern design, in The Man of Property, the "old oak tree" at the site of the house, a traditional symbol of Englishness, was also identified with Bosinney (Galsworthy 1906: 105). Writing from the vantage point of 1920 , Galsworthy has young Jolyon similarly meditate on the relationship of the tree with the house, more than a decade after its creation. In late nineteenth and twentieth-century fiction, the country house is perceived as quintessentially English, organically growing out of the landscape. Bosinney's far-sighted creation has similarly been incorporated into the landscape and the English architectural tradition:

that tree had seen, perhaps, all real English history; it dated, he shouldn't wonder, from the days of Elizabeth at least. When the house behind it [...] was three hundred years of age, that tree might still be standing there [...]. A Forsyte might perhaps still be living there, to guard it jealously [.... W] $]$ ould the giant London have lapped it around and made it into an asylum in the midst of a jerry-built wilderness? [...] It might even become one of the 'homes of England' - a rare achievement for a house in those degenerate days of building. And the aesthetic spirit, moving hand in hand with the Forsyte sense of possessive continuity dwelt with pride and pleasure on the ownership thereof. (Galsworthy 1920: 43-44)

Here, Galsworthy expresses his own nostalgia in light of the "jerrybuilt" suburban developments of the Edwardian and post-war periods. 
In this evocation of the timeless country house which elides historical change and conflict, the Forsytes are reconciled with Bosinney and modernity is reconciled with tradition. This unlikely reconciliation contrasts sharply with the nuanced accounts of historical periodisation and seems to undercut Galsworthy's social critique of possessive materialism and the life-changing effects of house design.

However, he achieves a more successful reconciliation of nostalgia and modernity in the Edwardian interlude 'Awakening', also written in 1920, but set in the summer of 1909. It is told from the perspective of Irene's and Jolyon's son, Jon, and recounts his adventures and family life at Robin Hill. This tale draws on Edwardian pastoral literature and foregrounds the potentially subversive and modern elements of this mode. Gavin and Humphries note that in Edwardian fiction, such as Kenneth Grahame's The Wind in the Willows (1909) and his earlier 1895 novel The Golden Age, the child achieves "autonomy, integrity and agency" (Gavin and Humphries 2009: 11), as Jon "led a lonely life of make-believe during those five weeks of summer weather", rummaging through the stories of King Arthur and the Round Table (Galsworthy 1920: 306). In this context, the tale's depiction of a mythic rural England is woven into the vision of a child whose modernity is emphasised. Galsworthy once again employs his meticulous dating to characterise Jon as "the child of 1901", who had "come to consciousness when his country, just over that bad attack of scarlet fever, the Boer War, was preparing for the Liberal revival of 1906" (Galsworthy 1920: 300). Furthermore, Jon's vision of happy family life is distinctly unconventional: his first images of his mother Irene "smoothing his forehead" and "being in the nature of a goddess" take on pagan overtones when it is revealed that she never attends church and only worships Pan, "the Goaty God who skips about in wild and beautiful places" (Galsworthy 1920: 300, 302 , 310). As neo-paganists, this neo-Edwardian family value creativity, sexuality and the natural world, live in a house designed by an architect who "adored" the Greek values of "beauty and symmetry", and reject high Victorian values of organised religion, acquisition and possession of property and people (Galsworthy 1915: 338-339). As in the work of Grahame, and in J. M. Barrie's Peter Pan (1904), the mythical past and the classical Golden Age become sources of social renewal, in contrast to imperial and country-house narratives which are associated with Victorian possessiveness. In this 
brief interlude, then, Galsworthy departs from Victorian social realism and neo-Victorian social critique to depict a neo-Edwardian world that is, admittedly, a self-contained idyll, but which nevertheless projects a hopeful and provocative vision of the modern family through the eyes of the twentieth-century child.

\section{Neo-Victorian/Neo-Edwardian Television Adaptations}

The 1967 and 2002 television adaptations of The Forsyte Saga have become implicated in the meanings attached to neo-Victorian and neoEdwardian inflected culture in the twenty-first century. As Imelda Whelehan has observed of literary adaptation, "gender, class and other social differences are inevitably ideologically reconstructed in our own image" (Whelehan 1999: 13), and critical responses to the Forsyte serialisations also reveal the changing cultural status of television and its role in shaping public perceptions of the nationfamily and its history. The 1967 BBC adaptation coincided with a plethora of re-creations of the Victorian past, including the rise of the neo-Victorian novel and of the 'heritage film'. Hargreaves suggests that nostalgic feelings for the "cultural signs" of the Victorians arose at a time when what Cora Kaplan calls the "libertarian impulses" of the decade seemed to be reacting strongly against "Victorian values" (qtd. Hargreaves 2009: 25). Hargreaves explains this dynamic in Oedipal terms, quoting a contemporary Radio Times reviewer, who similarly stated that "the ghosts of Victorianism are still with us, above all in emotional terms" (Hargreaves 2009: 25). Hargreaves lists the examples of "Victorian and Edwardian music-hall influences on the Beatles' album Sergeant Pepper's Lonely Hearts Club Band, the revival of Art Nouveau and television series like Adam Adamant Lives!" (Hargreaves 2009: 28). ${ }^{9}$ These examples, however, reveal a range of conflicting responses to the period, which were in turn nostalgic, parodic and openly critical.

The 1967 Forsyte Saga is a representative example of the heritage film, insofar as the narrative challenged the tenets of Victorian marriage (notably, in Soames's rape of Irene), but this critical social commentary was occasionally obscured by the

\footnotetext{
${ }^{9}$ For example, Adam Adamant Lives! comically explored the cultural differences between a 1960s girl and a late Victorian gentleman, and often critiqued Victorian male chivalry.
} 
pictorialist mise-en-scene which dwelt nostalgically on costumes and objects, portraying "history as heritage" (Higson 2003: 40). Whereas neo-Victorian novelists of this period, such as Fowles and Rhys, used formal experimentation to produce a sense of estrangement from the Victorian past, this adaptation deployed the realist aesthetic that would come to characterise heritage film: a use of panoramic shots of the Forsyte residences and close-ups of Irene's sumptuous costumes, which mirrored Galsworthy's own use of detailed description. This adaptation's neo-Victorian critique, then, was undermined by formal structures that encouraged a nostalgic gaze. Furthermore, this product of "heritage television" was granted the specific role of uniting the nation-family; The Forsyte Saga grew into a flagship programme for the newly-launched channel BBC2, and quickly became implicated in debates about the BBC's status as a national broadcaster and about its representation of Britain's past (Hargreaves 2009: 37). The Forsyte Saga's legendary status was soon established, when a third of the British nation (17 million) watched the serial's repeat in 1968. This unifying function was disseminated by reviewers, one of whom wrote: "one hears of owners of $\mathrm{BBC} 2$ sets inviting their friends in for Forsyte parties" (Anon 1967: n.p.). The medium of television, then, was dominated by a realist aesthetic that presented the past as 'edutainment' for the whole family, whereby the visual spectacle of Victorian family life enticed the viewer to watch and ask questions about a period that was perceived as the locus of modern cultural change. However, discomfort about social issues, including divorce, could be comfortably displaced onto the past. ${ }^{10}$

When the 2002 Granada television dramatisation of The Forsyte Saga was announced, it was within a new broadcasting landscape of multiple terrestrial, cable and satellite television channels. In the twenty-first century, fragmented television audiences

\footnotetext{
10 ITV's response to The Forsyte Saga was a neo-Edwardian drama, Upstairs Downstairs, which featured suffragettes and cross-class love affairs (1971-75). Cocreator Jean Marsh claimed that "[t]he idea was that it would be turn of the century...And it was going to strongly feature downstairs...I had a passion to show the truth about where we both came from $[. .$.$] we always wanted it to be rather political"$ (qtd. Sweet 2005, unbracketed ellipses in the original). The BBC's Edwardian riposte to this production was The Duchess of Duke Street (1976), made by Upstairs, Downstairs producer John Hawkesworth, which featured a successful lower-middleclass cook. In 1970s television, then, the Edwardian era was often identified with modernity and social mobility.
} 
meant that the image of the nation-family glued to one channel was a distant memory: one critic commented wistfully that "we shall never have that long-running communal television experience again" (Billen 2002: 32). Indeed, a prominent feature of the critical responses was a nostalgic longing for this television audience, which revealed the extra-textual, wider cultural appeal of the 1967 production's version of Victorian nation and family. The reviews dwelt on reminiscences of 1960 s domestic appliances, which contextualised the viewing experience and seemed analogous to the heritage appeal of the saga itself: "perhaps the time has come to revive the stay-at-home spirit of 1967 - crack open the Mateus Rose, turn on the chianti-bottle table light, break out the Black Forest gateau" (Robson 2007: 20). These objects were then subsumed into conservative nostalgic narratives about family life, itself conflated with religious and educational values. The 1967 production "was regarded as family viewing, educational and rewarding [...] even the scene when Soames rapes his wife Irene was deemed suitable for children", and television adapted to, rather than disrupted, traditional patterns of religious observance (Robson 2007: 20). Justifying his decision to postpone Evensong, "the important thing is that people worship God, not that they should worship him at $6.30 \mathrm{pm}$, wrote a Cirencester vicar in a letter to The Times, justifying his surrender" (Robson 2007: 20). Here, the united television audience of the 1960s is imagined not as a club of vicarious neo-Victorian revisionists, but as the dutiful inheritors of the Victorian family ideal, passively consuming the 'edutainment' of the national broadcaster. Indeed, the 1960s almost represent a technologically upgraded Victorian age, where inventions such as television are a benign force for social cohesion. By contrast, reviews of the 2002 adaptation suggested that its technical sophistication merely reflected postmodern (and, of course, Forsyte) obsession with style and consumption, in contrast to the perceived social idealism of the 1960s: "what it is about is property, ownership, money, all the things we're interested in much more than in the Sixties when people were protesting about the Vietnam War" (Billen 2002: 32). For Bonnie Greer, the visual spectacle mimicked the aspirational consumerism of contemporary reality television "like some fantasy upper-class ideal Home Exhibition full of minimally decorated rooms", rather than functioning to recreate the period faithfully (Greer 2002: 11). However, as I have shown, both adaptations deployed visual spectacle 
to draw the viewer to its own vision of the Victorian past's relation to the present historical moment.

The recent dawn of the twenty-first century led some reviewers to contemplate the saga's Edwardian antecedents and to identify with them. For one critic, "the wheel has turned full circle since then and the values questioned by Galsworthy in the original novels seem very reflective of today's Western society" (Portman 2002: 7). For this critic, then, the novels reflected a cyclical narrative of history, where the consumer-oriented spirit of the early twenty-first century is a reflection of Galsworthy's own turn-of-the-century society and the 2002 adaptation functions as a cautionary tale. In general, however, few critics made any distinction between the Victorian and Edwardian periods and those that did - such as Malcolm Bradbury in one of my opening quotations - define the Edwardian era by its proximity to the Great War, rather than by its differences from the Victorian era. While I suggest that paying equal attention to the saga's Edwardian antecedents fragments the monolithic label of (neo-)Victorianism and re-focuses attention on both contemporary and subsequent attitudes to periodisation, it may well be that these debates within the academy are conducted somewhat differently amongst other audiences. It is questionable whether many contemporary, non-expert viewers can now distinguish between two distant pasts, by identifying costumes and objects. Yet the recent revival of heritage television, in the form of ITV's Downton Abbey, set in 1912, and the BBC's 1920s sequel to Upstairs, Downstairs (2010), suggests that the neo-Edwardian may equal, or overtake, the neo-Victorian drama in popularity. Indeed, the proximity of the Great War - which remains strong in the national consciousness - in both of these dramas makes the Edwardian period seem more tangible and connected to present-day conflicts. Perhaps too, the neoVictorian should be taken to refer to a mode of historical enquiry, as well as to a specific period. Galsworthy's proto-modernist tendencies led him to rebel against his Victorian forefathers, while remaining attached to them, and thus he produced a distinctive mode of transitional neo-Victorian fiction. The increasing distance from the Victorian past has led to a decreased family resemblance, with more nearly related and better remembered eras exerting powerful influences through newer, better-preserved media. Hence, the postmodern attitude of historical re-vision may progressively re-focus 
on the early twentieth century, on the 'birth of now' with which the Edwardians are increasingly associated. The history of The Forsyte Saga indicates these shifting trends in the history of neo-Victorianism, demonstrating that the boundaries between nostalgic and re-visionary recuperations of the Victorian family remain fluid, if not inseparable.

\section{Bibliography}

Anon. 1967. 'A great "saga" begins on television', Daily Telegraph (6 January): n. p. Ardis, Ann. 2002. Modernism and Cultural Conflict, 1880-1922. Cambridge: Cambridge University Press.

Batchelor, John. 1982. The Edwardian Novelists. London: Duckworth and Co.

Billen, Andrew. 2002. 'The Forsytes Return', The Evening Standard (14 March): 32.

Bradbury, Malcolm. 2000. 'Can We Love the Forsytes as Before?', The New Statesman (21 August): n.p. On-line at: http://www.newstatesman.com/200008210004 (consulted 16.02.2010).

Bullen, J.B. (ed.) 1997. 'Introduction', in Writing and Victorianism. London: Longman: 1-13.

Delap, Lucy, Ann Heilmann and Sue Thomas (eds.). 2006. Anti-Feminism in Edwardian Literature. London: Thoemmes Continuum.

Galsworthy, John. 2007a. The Man of Property [1906]. London: Headline Review.

—. 2007b. 'Indian Summer of a Forsyte' [1915]. In Galsworthy (2007a): 321367.

2007c. In Chancery [1920]. London: Headline Review.

2007d. 'Awakening' [1920]. In Galsworthy 2007c: 299-319.

Gavin, Adrienne E. 2009. 'Intangible Children: Longing, Loss and the Edwardian Dream Child in J.M. Barrie's The Little White Bird and Rudyard Kipling's 'They'”. In Gavin and Humphries (2009): 53-72.

- and Andrew F. Humphries (eds.). 2009. Childhood in Edwardian Fiction: Worlds Enough and Time. Houndmills, Basingstoke: Palgrave Macmillan. and Andrew F. Humphries. 2009. 'Worlds Enough and Time: The Cult of Childhood in Edwardian Fiction' In Gavin and Humphries (2009): 1-20.

Girouard, Mark. 1994. Life in the English Country House: A Social and Architectural History. New Haven: Yale University Press.

Greer, Bonnie. 2002. 'I will turn off the new Forsyte Saga', Mail on Sunday, (7 April): 11.

Hapgood, Lynne. 2000. 'The Unwritten Suburb: Defining Spaces in John Galsworthy's The Man of Property', in Hapgood, Lynne (ed.), Outside Modernism: In Pursuit of the English Novel, 1900-30. Houndmills, Basingstoke: Palgrave Macmillan: 162-179.

Hargreaves, Tracy. 2007. 'Nostalgic Retrieval: Sexual Politics, Cultural Aesthetics and Literary Form in John Galsworthy's The Forsyte Saga', English 56 (Summer): 127-145.

2009. "There's No Place Like Home": History and Tradition in The Forsyte Saga and the BBC', Journal of British Cinema and Television 6:1: 21-40. 
Heilmann, Ann, and Mark Llewellyn. 2010. Neo-Victorianism: The Victorians in the Twenty-First Century, 1999-2009. Houndmills, Basingstoke: Palgrave Macmillan.

Higson, Andrew. 2003. English Heritage, English Cinema: Costume Drama since 1980. Oxford: Oxford University Press.

Kaplan, Cora. 2007. Victoriana: Histories, Fictions, Criticisms. Edinburgh: Edinburgh University Press.

Lawrence, D.H. 1986. 'John Galsworthy' [1928], in Lawrence, D.H., Selected Literary Criticism. London: Heinemann: 118-131.

Miller, Jane Eldridge. 1997. Rebel Women: Feminism, Modernism and the Edwardian Novel. Chicago: University of Chicago Press.

Mottram, R.H. 1956. For Some We Have Loved: An Intimate Portrait of John and Ada Galsworthy. London: Hutchinson.

PBS. n.d. 'Masterpiece Theatre - The Forsyte Saga'. Online at: http://www.pbs.org/wgbh/masterpiece/forsyte/notes.html (consulted 10.07.2010).

Portman, Jamie. 2002. 'A racier Forsyte Saga hits the small screen', Pembroke Observer (25 September): 7.

Robson, David. 2007. 'Foryste at 40', Daily Express (5 January): 20.

Sweet, Matthew. 2005. 'Fay Weldon and Jean March Discuss Upstairs, Downstairs' [Interview] (15 December). Online at: http://www.bfi.org.uk/features/interviews/weldon-marsh.html (consulted 10.07.2010)

Whelehan, Imelda. 1999. 'Adaptations: The contemporary dilemma', in Cartmell, Deborah, and Imelda Whelehan (eds.), Adaptations: From Text to Screen, Screen to Text. London \& New York: Routledge: 3-19.

Wilson, Cheryl A. 2008. '(Neo-)Victorian Fatigue: Getting Tired of the Victorians in Conrad's The Secret Agent', Neo-Victorian Studies 1(1) (Autumn): 19-40.

Woolf, Virginia. 1966. 'Mr Bennett and Mrs Brown' [1923], in Virginia Woolf, Collected Essays, Vol. One (ed. Leonard Woolf). London: Hogarth Press: 319-337. 